\title{
UJI VALIDITAS MODUL PROGRAM TANGKAL HOAKS UNTUK MENINGKATKAN KETERAMPILAN PENGAMBILAN KEPUTUSAN DIGITAL NATIVE DALAM MENENTUKAN BERITA HOAKS
}

\section{VALIDITY TEST OF PROGRAM TANGKAL HOAX MODULE TO IMPROVE DIGITAL NATIVE DECISION-MAKING SKILLS IN DETERMINING HOAX NEWS}

\author{
Intan Yulia Rainaz ${ }^{1}$, Nofrans Eka Saputra ${ }^{2}$ \\ ${ }^{12}$ Department of Psychology, Jambi University/ intanrainaz08@gmail.com
}

\begin{abstract}
Background The massive spread of hoaxes in the digital era has had a negative impact, especially on groups digital native as the largest internet users. Although digital native is associated as a group that has the ability to use technology and the internet, in receiving information, this group's decision-making ability to distinguish true information from hoax is still far from perfect. So that we need a program to overcome these problems.
\end{abstract}

Method This study aims to test the content validity of the program tangkal hoax module on digital native decision-making skills in determining hoax news. The type of research used is module validation research using four validators selected based o ntechnique purposive to test the suitability of the module content with the objectives to be achieved. The method of data analysis used descriptive analysis using Aikens'V.

Results This study shows that the results of the validation of the module content assessed by the validator have a $V$ score in the range 0.75-0.88. The results of the validation of the measuring instruments that were assessed by the validator had a range of $V$ score moving from 0.56 to 0.88. Based on the results of the validity test of the hoax deterrence program, which was assessed by the validator, it was included in the valid criteria with several suggestions for improvement.

Conclusion Based on the results of the module content validity test, it can be concluded that the program tangkal hoax module is at a good validity level.

Keywords: Module Validity, Decision Making Skills, Program Tangkal Hoax, Digital Native

\begin{abstract}
ABSTRAK
Latar Belakang Masifnya penyebaran hoaks di era digital mendatangkan dampak negatif terutama pada kelompok digital native sebagai pengguna internet terbanyak. Meskipun digital native diasosiasikan sebagai kelompok yang memiliki kemampuan dalam menggunakan teknologi dan internet, namun dalam menerima suatu informasi, kemampuan pengambilan keputusan kelompok ini untuk membedakan informasi yang benar dan hoaks masih jauh dari sempurna. Sehingga diperlukan sebuah program untuk mengatasi permasalahan tersebut.

Metode Penelitian ini bertujuan untuk menguji validitas modul program tangkal hoaks terhadap keterampilan pengambilan keputusan digital native dalam menentukan berita hoaks. Jenis penelitian yang digunakan yaitu riset validasi modul dengan menggunakan empat orang validator yang dipilih berdasarkan teknik purposive untuk menguji kesesuaian isi modul dengan
\end{abstract}


tujuan yang hendak dicapai. Metode analisis data menggunakan analisis deskriptif dengan menggunakan Aikens' $\mathrm{V}$.

Hasil Penelitian ini menunjukkan hasil validasi isi modul yang dinilai oleh validator yaitu memiliki angka Skor V dengan rentang 0,75-0,88. Hasil validasi alat ukur yang dinilai oleh validator memiliki rentang angka Skor V bergerak dari 0,56-0,88. Berdasarkan hasil uji validitas modul program tangkal hoaks yang dinilai oleh validator termasuk dalam kriteria valid dengan beberapa saran perbaikan.

Kesimpulan Berdasarkan hasil uji validitas isi modul, dapat disimpulkan bahwa modul program tangkal hoaks berada pada tingkat validitas yang baik.

Kata Kunci: Validitas Modul, Keterampilan Pengambilan Keputusan, Program Tangkal Hoaks, Digital Native

\section{Pendahuluan}

Arus teknologi dan informasi berkembang sangat pesat di era digital. Perkembangan teknologi dan informasi tersebut di satu sisi dapat menguntungkan dan memudahkan proses pekerjaan manusia, namun sisi lain juga dapat menimbulkan kerugian dan perpecahan ketika disalahgunakan.

Salah satu ciri pesatnya perkembangan teknologi dan informasi adalah dengan adanya internet (Septiani, 2010). Internet memudahkan individu untuk mengakses dan membagikan berbagai macam informasi dengan skala tak terbatas. Internet juga menjadi satu hal yang tidak bisa dipisahkan dari kehidupan masyarakat sehari-hari.

Prensky (2001) membagi masyarakat di era digital ini menjadi dua kategori yaitu digital immigrant dan digital native. Digital immigrant adalah kelompok yang lahir sebelum era digital (sebelum 1980-an) dan mulai mengadopsi teknologi digital setelah mereka dewasa. Sedangkan digital native merupakan kelompok yang lahir di era digital yakni setelah tahun 1980an dimana mereka telah terbiasa dengan teknologi dan internet (Prensky, 2001).

Berdasarkan survei APJII (2019), kelompok pengguna internet terbesar adalah para digital native. Kelompok dengan rentang usia 15-19 tahun berada di posisi pertama (91\%), diikuti kelompok usia 20-24 tahun $(88,5 \%)$, dan kelompok usia 25-29 tahun $(82,7 \%)$. Digital native menghabiskan rata-rata lebih dari empat jam waktunya dalam satu hari untuk menggunakan internet. Berkomunikasi lewat instant chatting, media sosial, serta mencari informasi merupakan aktivitas-aktivitas yang sering mereka lakukan (APJII, 2019).

Digital native senang mencari informasi dan ilmu-ilmu baru melalui media sosial mereka. Penelitian (Greenwood et al., 2016) menunjukkan 88 persen orang muda di Amerika mendapatkan berita dari Facebook dan media sosial lainnya. Bahkan 28 persen dari mereka yang berusia 18-24 tahun mengungkapkan bahwa media sosial adalah sumber informasi atau berita utama mereka. Sejalan dengan penelitian tersebut, menurut Rusadi (2014) generasi digital native lebih mengutamakan konsumsi media berita berbasis internet dibanding dengan generasi digital immigrant.

Digital native dicirikan sebagai individu yang memiliki pengetahuan tentang teknologi (Prensky, 2001). Mereka memahami penggunaan perangkat teknologi dan fitur seperti email, pesan instan, internet, dan pesan teks (Rahmawati et al., 2019). Mereka dapat menggunakan perangkat teknologi untuk mengakses informasi dari berbagai sumber. Kemampuan digital native untuk mendapatkan informasi tanpa batas di era internet saat ini tidak selalu diikuti oleh kemampuan mereka untuk mengevaluasi kualitas informasi (Manalu et al., 2018).

Salah satu peristiwa buruk yang dialami digital native dalam akses informasi di era internet adalah maraknya konsumsi 
berita, gambar, maupun video hoaks (Supratman, 2018).

Hoaks berasal dari bahasa Inggris yang berarti berita bohong atau pemberitaan palsu. Hoaks adalah informasi yang secara fakta tidak benar, tetapi dibuat seolah-olah benar. Secara sederhana hoaks dapat diartikan sebagai sebuah informasi palsu yang sengaja dibuat dan tidak dapat dipertanggungjawabkan kebenarannya. (Bakri et al., 2019).

Data dari masyarakat anti fitnah Indonesia (Media Release, 2018) menyebutkan bahwa sepanjang tahun 2018 mereka telah melakukan debunking atau meneliti kebenaran suatu berita terhadap 997 hoaks yang beredar di tengah masyarakat. Data hoaks perbulannya dapat dilihat pada Grafik 1 berdasarkan data dari Litbang MAFINDO.

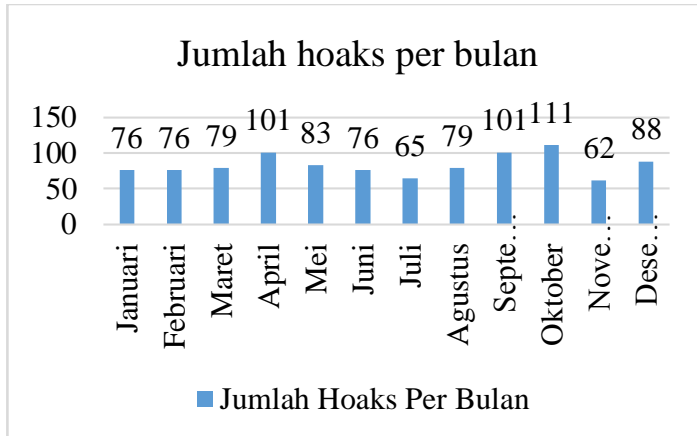

\section{Grafik 1. Jumlah Hoaks dalam Kurun Waktu 2018}

Berdasarkan grafik tersebut, hoaks mengalami fluktuasi setiap bulannya di sepanjang 2018. Hoaks dengan isu politik dan agama menjadi yang paling banyak beredar di masyarakat (Media Release, 2018). Sedangkan di tahun 2019, Kementerian Komunikasi dan Informatika mencatat terdapat 3.801 temuan isu hoaks dan 15.361 aduan masyarakat tentang hoaks (Kominfo, 2019). Hoaks terbanyak terjadi pada 3 bulan masa berlangsungnya pemilihan presiden yakni bulan Maret, April, dan Mei. Sejalan dengan data MAFINDO, isu politik masih menjadi isu yang paling banyak dijadikan hoaks yakni sebesar 922 konten dari temuan isu hoaks yang diperoleh oleh Kominfo.
Hoaks dapat memberikan dampak buruk terhadap kesehatan mental seseorang seperti post-traumatic stress syndrome (PTSD), menimbulkan kecemasan, sampai kekerasan (Erdelyi, 2020). Hoaks dirancang untuk memancing respons emosional dari pembaca/ pemirsa, seringkali bersifat menghasut dan dapat menimbulkan perasaan marah, kecurigaan, kecemasan, dan bahkan depresi dengan mendistorsi pemikiran kita.

Dalam menangani penyebaran berita hoaks, pemerintah sudah melakukan beberapa tindakan. Seperti pemblokiran situs-situs yang terindikasi menyebarkan hoaxs dan membuat peraturan perundangundangan yang memadai yakni Pasal 28 ayat 1 dan 2 UU No. 11 Tahun 2008 tentang ITE, Pasal 14 dan 15 UU No. 1 Tahun 1946, Pasal 311 dan 378 KUHP, serta UU No. 40 tahun 2008 tentang penghapusan diskriminasi ras dan etnis, pembentukan Badan Siber Nasional sebagai regulator seluruh aktivitas di dunia siber, serta melakukan kerjasama dengan Dewan Pers dan Facebook (Siswoko, 2017). Namun penyebaran berita bohong ini masih menjamur dan terdapat banyak digital native yang mempercayainya.

Berdasarkan penelitian Rahmawati et al. (2019), digital native dianggap terlalu percaya diri akan tingkat kemampaun literasi mereka dalam menilai berita bohong. Selain itu mereka juga cenderung menganggap kemampuan mereka dalam konsumsi media digital lebih baik daripada generasi digital immigrant. Padahal digital native juga membutuhkan orang dewasa lain untuk memverifikasi informasi atau berita yang mereka terima.

Hasil penelitian tersebut juga didukung oleh penelitian dari (Manalu et al., 2018) yang menunjukkan bahwa berdasarkan pola konsumsi media, pengguna media yang mempunyai risiko lebih tinggi terpapar berita palsu adalah mereka yang berada dalam kelompok usia 15-30 tahun.

Hal ini juga berarti bahwa kelompok usia ini adalah pengguna media dengan kecenderungan untuk mengkonsumsi (dan kemungkinan besar akan mendistribusikan) 
berita palsu. Salah satu kelompok yang tergolong dalam usia ini adalah mahasiswa.

Mahasiswa dengan daya kritis yang dimiliki kadang meragukan kredibilitas sebuah informasi yang hendak didistribusikan, namun tetap tidak mampu melakukan penelusuran untuk memastikan kebenarannya. Kemampuan untuk memilih dan memilah pesan yang boleh dan tidak boleh di-share sangat lemah. Informasi yang diredistribusi sering dicerna secara subyektif dengan menggunakan indikator informasi yang menarik, penting, dan bermanfaat. Mahasiswa melakukan proses penyaringan informasi terkait redistribusi konten media sosial berdasarkan preferensi dan tendensi pribadi (Muannas, 2018).

Ketika individu menangkap informasi kemudian digunakan untuk melakukan aktivitas kognitif tingkat tinggi, salah satunya yaitu mengambil keputusan (Santrock, 2007). Mahasiswa dalam tahapan perkembangannya berada pada masa remaja akhir. Pada masa remaja ini seseorang akan lebih banyak dihadapkan pada kondisikondisi untuk mengambil keputusan. Seorang remaja meskipun telah mampu mengambil keputusan, namun tingkat pengambilan keputusan remaja jauh dari sempurna. Emosi remaja yang cenderung tempramen seringkali menghambat pengambilan keputusan (Santrock, 2007).

Secara empiris temuan di lapangan menunjukkan bahwa mahasiswa sebagai kelompok digital native pernah merasa tertipu dengan berita hoaks. Berita yang awalnya dianggap benar, ternyata merupakan hoaks. Konten beritanya pun beragam, mulai dari teks berita, video, sampai penipuan undian.

Selain itu penanganan dari pemerintah seperti yang sudah disebutkan sebelumnya lebih banyak berbasis pada konten hoaks bukan pada individu penerima hoaks itu sendiri. Oleh karena itu diperlukan suatu kegiatan untuk meningkatkan keterampilan digital native dalam mengambil keputusan untuk menentukan berita hoaks yang mereka terima. Adapun kelompok digital native yang dimaksud pada penelitian ini adalah mahasiswa program studi ilmu Keperawatan angkatan 2019 Universitas Jambi berjumlah 158 orang.

Dalam menentukan suatu keputusan, elaborasi dan klarifikasi terkait informasiinformasi yang diperlukan sangat penting (Maloney, 2007). Hal ini dapat dicapai dengan menghadapkan seseorang dengan keadaan nyata dari masalah yang ia hadapi dan diskusi kelompok kecil. Sejalan dengan hal tersebut, Santrock (2007) mengatakan bahwa salah satu strategi untuk meningkatkan keterampilan pengambilan keputusan adalah dengan memberikan peluang kepada individu untuk lebih banyak terlibat dalam pemecahan masalah kelompok. Diskusi kelompok juga efektif dalam meningkatkan harga diri dan gaya coping yang positif (Colakkadioglu \& Celik, 2016).

Merujuk pada beberapa fakta dan literatur maka peneliti mengajukan sebuah program melalui diskusi kelompok kecil untuk meningkatkan keterampilan pengambilan keputusan digital native dalam menentukan berita hoaks yang mereka terima sebagai upaya pencegahan maraknya penyebaran hoaks di dunia digital. Program ini dinamakan program tangkal hoaks.

Program ini terdiri atas empat sesi; Pertama, peserta akan disajikan lima berita. Setiap nomor akan terdapat dua berita, satu berita asli dan satu berita hoaks. Peserta akan diminta menentukan manakah diantara kedua berita tersebut yang merupakan berita hoaks.

Kedua, ayo kenali hoaks melalui diskusi kelompok. Peserta akan dibagi ke dalam kelompok-kelompok kecil beranggotakan 4-5 orang dengan satu cofasilitator. Fasilitator akan terlebih dahulu memaparkan informasi mengenai definisi, ciri, jenis, dan cara mengenali hoaks. Kemudian, tiap peserta akan diminta mengemukakan argumen terkait jawaban mereka di hadapan anggota kelompoknya dengan berdasarkan informasi yang telah didapat untuk mendukung argumen mereka. Dengan mendengarkan beberapa informasi dan pendapat, peserta diharapkan mampu 
mendapatkan beberapa sudut pandang dalam menilai suatu berita.

Ketiga, sesi memilih dengan tepat. Sesi ini merupakan kelanjutan dari sesi kedua. Setelah berdiskusi, tiap kelompok diminta menentukan jawaban yang paling tepat untuk kelima soal disertai alasannya.

Keempat, sesi terampil hadapi hoaks. Sesi ini merupakan pemaparan dan penerapan keputusan yang telah diambil sebelumnya, dimana peserta akan memaparkan hasil diskusi mereka ke forum. Selain itu, fasiliator juga akan mengajak peserta mengelompokkan hoaks dan mempelajari tool atau media yang dapat meningkatkan keterampilan dalam menghadapi hoaks.

Modul program yang dirancang sebelum dapat diimplementasikan, harus diuji validitasnya. Hal ini bertujuan untuk mengetahui kesesuaian isi atau materi modul dengan tujuan yang hendak dicapai.

Berdasarkan uraian di atas, peneliti tertarik untuk melakukan penelitian mengenai uji validitas modul program tangkal hoaks untuk meningkatkan keterampilan pengambilan keputusan digital native dalam menentukan berita hoaks.

\section{Metode}

Penelitian ini bertujuan untuk menguji validitas isi modul program tangkal hoaks terhadap keterampilan pengambilan keputusan digital native dalam menentukan berita hoaks. Jenis penelitian yang digunakan yaitu riset validasi modul.

Metode yang digunakan dalam penelitian ini yaitu studi deskriptif dengan model 3D (define, design, develop). Data penelitian diperoleh dari tiga tahapan yaitu:

1. Tahap pertama (define)

Prosedur penelitian tahap pertama dilakukan pada saat menelusuri gambaran permasalahan di lapangan mengenai keterampilan pengambilan keputusan digital native dalam menghadapi hoaks. Tahap define ini dilakukan melalui wawancara dengan tiga orang mahasiswa program studi Ilmu Keperawatan Universitas Jambi angkatan 2019 sebagai kelompok digital native untuk mendapatkan gambaran langsung bagaimana pandangan, pengalaman dan cara pengambilan keputusan generasi ini dalam mendapatkan berita hoaks. Analisis yang digunakan pada tahap ini yaitu menggunakan analisis literatur mengenai program pencegahan hoaks, keterampilan pengambilan keputusan, dan digital native.

2. Tahap kedua (design)

Pada tahap kedua merupakan tahap penyusunan modul dengan menentukan metode dalam program tangkal hoaks serta menyusun urutan sesi dalam program. Program tangkal hoaks terdiri atas empat sesi, yang mencakup empat aspek dari keterampilan pengambilan keputusan, yaitu pemberian media hoaks memuat aspek intelligence, ayo kenali hoaks memuat aspek design, memilih dengan tepat memuat aspek choice, dan terampil hadapi hoaks memuat aspek implementation. Program ini merupakan program yang telah dimodifikasi pelaksanaannya sesuai dengan kebutuhan assessment.

3. Tahap ketiga (develop)

Prosedur penelitian tahap ketiga (develop) merupakan tahapan memberikan modul yang telah dirancang oleh peneliti untuk divalidasi oleh ahli pakar atau professional judgement yang telah memiliki pengalaman di bidang yang sesuai dengan topik peneliti. Modul yang telah disusun dinilai oleh empat orang validator terdiri dari psikolog pendidikan, jurnalis, pakar literasi, dan pemeriksa fakta yang ditentukan dengan teknik purposive. Hasil evaluasi dari validator digunakan oleh peneliti guna memperbaiki materi modul yang telah dibuat.

Proses validasi yang dilakukan adalah validasi isi yaitu apakah modul yang telah dirancang sesuai kebutuhan digital native dalam menerima berita hoaks. Metode analisis data menggunakan analisis deskriptif dengan menggunakan Aikens' $\mathrm{V}$ (lembar validasi).

\section{Hasil}

Berdasarkan tahapan penelitian dengan model 3D (define, design, develop) diperoleh hasil sebagai berikut: 


\section{Tahap pertama (define)}

Tahapan pertama ini dilakukan guna melihat analisis kebutuhan di lapangan yang terkait dengan penyusunan modul program tangkal hoaks. Analisis yang digunakan dalam penelitian ini berupa analisis literatur mengenai program pencegahan hoaks, keterampilan pengambilan keputusan, serta karakteristik digital native.

a. Program tangkal hoaks

Suatu program yang dirancang untuk meningkatkan suatu keterampilan pengambilan keputusan digital native dalam menentukan berita hoaks melalui pemaparan langsung terhadap berita hoaks, pengenalan hoaks melalui diskusi kelompok kecil, memilih hoaks secara tepat, dan terampil dalam menghadapi hoaks.

b. Keterampilan pengambilan keputusan

Pengertian keterampilan

pengambilan keputusan merujuk pada definisi menurut Simon (Sari, 2018). Keterampilan pengambilan keputusan dalam konteks menentukan berita hoaks yaitu keterampilan seseorang dalam memilih suatu keputusan di antara beberapa pilihan melalui pengumpulan informasi (intelligence), mempertimbangkan beberapa alternatif (design), mengambil keputusan yang terbaik berdasarkan alasan yang rasional (choice), dan menerapkan keputusan yang diambil (implementation).

c. Digital native

Digital native merupakan generasi yang lahir di era teknologi digital dengan karakteristik kelahiran di atas tahun 2000 (Prensky, 2001). Kelompok usia ini telah biasa menggunakan teknologi dalam kehidupan sehari-hari. Pada penelitian ini kelompok digital native yang dimaksud merupakan kelompok mahasiswa dengan rentang usia 18-21 tahun.

\section{Tahap kedua (design)}

Pada tahap kedua merupakan tahap penyusunan modul dengan menentukan metode dalam program tangkal hoaks serta menyusun urutan sesi dalam program. Program tangkal hoaks terdiri atas empat sesi, yang mencakup empat aspek dari keterampilan pengambilan keputusan, yaitu pemberian media hoaks memuat aspek intelligence, ayo kenali hoaks memuat aspek design, memilih dengan tepat memuat aspek choice, dan terampil hadapi hoaks memuat aspek implementation. Program ini merupakan program yang telah dimodifikasi pelaksanaannya sesuai dengan kebutuhan assessment. Penjelasan akan program tersebut adalah sebagai berikut:

a. Pemberian media hoaks

Sesi pertama dalam program tangkal hoaks ini bertujuan untuk mengenalkan dan memaparkan langsung digital native dengan berita hoaks. Media yang digunakan yaitu media berita hoaks yang merupakan kumpulan berita hoaks dan fakta. Digital native akan diminta mengidentifikasi dan menentukan berita hoaks di antara kumpulan hoaks dan fakta yang diberikan.

b. Ayo, kenali hoaks

Sesi ini bertujuan memberikan informasi kepada digital native mengenai definisi, ciri, jenis, dan cara mengenali hoaks. Pelaksanaan sesi dilakukan dalam bentuk pemaparan informasi dan diskusi kelompok kecil. Digital native diminta mendiskusikan media berita hoaks yang telah diberikan pada sesi satu dengan kelompoknya berdasarkan informasi mengenai hoaks yang telah disampaikan.

c. Memilih dengan tepat

Sesi ini merupakan kelanjutan dari sesi kedua. Setelah berdiskusi, digital native diminta memutuskan manakah berita hoaks di antara kumpulan berita dalam media hoaks yang diberikan pada sesi satu berdasarkan hasil diskusi yang telah dilakukan.

d. Terampil hadapi hoaks

Sesi ini, digital native akan lebih banyak mempraktikkan keterampilanketerampilan dalam menghadapi hoaks. Di awal sesi digital native akan diminta mengelompokkan hoaks yang telah mereka pilih dalam diskusi kelompok sebelumnya berdasarkan ciri dan jenisnya. Kemudian digital native mempraktikkan cara mencari keaslian foto dan video melalui situs google reverse, yandex, tineye, dan fake image 
Uji Validitas Modul Program Tangkal Hoaks untuk Meningkatkan Keterampilan Pengambilan Keputusan Digital Native dalam Menentukan Berita Hoaks

detector dan mengakses situs penyedia narasi counter hoaks seperti turnbackhoax, laporan isu hoaks kominfo, dan cekfakta.com.

\section{Tahap ketiga (develop)}

Prosedur penelitian tahap ketiga (develop) merupakan tahapan memberikan modul yang telah dirancang oleh peneliti untuk divalidasi oleh ahli pakar atau professional judgement yang telah memiliki pengalaman di bidang yang sesuai dengan topik penelitian. Hasil validasi dan saransaran perbaikan yang diberikan oleh validator digunakan untuk melakukan revisi modul.
Proses memperoleh validator dilakukan dengan menggunakan teknik purposive. Validator professional judgement penelitian yang berjumlah empat orang, terdiri dari psikolog pendidikan, jurnalis dari Aliansi Jurnalis Independen Kota Jambi, pakar literasi dari Kantor Bahasa Provinsi Jambi, dan pemeriksa fakta dari Masyarakat Anti Fitnah Indonesia (MAFINDO).

Pelaksanaan kegiatan penilaian modul penelitian dilakukan melalui diskusi dengan professional judgmenet baik secara daring maupun luring disesuaikan dengan kesediaan dari tiap validator. Hasil validasi modul dan alat ukur ditampilkan dalam tabel 1 dan 2.

Tabel 1. Hasil Validasi Modul

\begin{tabular}{|c|c|c|c|c|c|c|c|c|}
\hline \multirow{2}{*}{ Sesi } & \multirow{2}{*}{ No Item } & \multicolumn{4}{|c|}{ Skor } & \multirow{2}{*}{$\begin{array}{l}\text { Total } \\
\text { Nilai }\end{array}$} & \multirow{2}{*}{ Validitas } & \multirow{2}{*}{ Kategori } \\
\hline & & $\mathbf{P 1}$ & $\mathbf{P 2}$ & P3 & $\mathbf{P 4}$ & & & \\
\hline \multirow{2}{*}{ Sesi 1} & 1 & 4 & 3 & 5 & 5 & 17 & 0,81 & Sangat Tinggi \\
\hline & 2 & 4 & 3 & 5 & 4 & 16 & 0,75 & Tinggi \\
\hline \multirow{3}{*}{ Sesi 2} & 3 & 4 & 3 & 5 & 4 & 16 & 0,75 & Tinggi \\
\hline & 4 & 4 & 3 & 5 & 4 & 16 & 0,75 & Tinggi \\
\hline & 5 & 4 & 3 & 5 & 4 & 16 & 0,75 & Tinggi \\
\hline Sesi 3 & 6 & 4 & 4 & 5 & 3 & 16 & 0,75 & Tinggi \\
\hline \multirow{4}{*}{ Sesi 4} & 7 & 4 & 4 & 5 & 4 & 17 & 0,81 & Sangat Tinggi \\
\hline & 8 & 4 & 3 & 5 & 4 & 16 & 0,75 & Tinggi \\
\hline & 9 & 4 & 3 & 5 & 4 & 16 & 0,75 & Tinggi \\
\hline & 10 & 4 & 4 & 5 & 5 & 18 & 0,88 & Sangat Tinggi \\
\hline
\end{tabular}

Rentang angka $\mathrm{V}$ yang dapat diperoleh adalah $0-1,00$. Setiap skor V yang melebihi dari angka 0,50 dapat dianggap sebagai indikasi adanya validitas isi modul yang baik (Azwar, 2018). Skor angka yang ditampilkan dalam tabel 1 dapat diinterpretasikan sebagai koefisien yang tinggi. Data tabel 1 menunjukkan skor $\mathrm{V}$ bergerak dari angka 0,75-0,88 dengan kategori tinggi sampai sangat tinggi.
Subbagian modul pada masing-masing sesi dari program tangkal hoaks memiliki isi yang baik dengan rentang skor di atas 0,50. 
Tabel 2. Hasil Validasi Alat Ukur

\begin{tabular}{|c|c|c|c|c|c|c|c|c|}
\hline \multirow{2}{*}{ Aspek } & \multirow{2}{*}{ No Item } & \multicolumn{4}{|c|}{ Aspek } & \multirow{2}{*}{ Total Nilai } & \multirow{2}{*}{ Validitas } & \multirow{2}{*}{ Kategori } \\
\hline & & P1 & P2 & P3 & P4 & & & \\
\hline \multirow{11}{*}{ Intelligence } & 1 & 4 & 3 & 4 & 3 & 14 & 0,63 & Tinggi \\
\hline & 2 & 4 & 2 & 4 & 4 & 14 & 0,63 & Tinggi \\
\hline & 3 & 4 & 3 & 5 & 4 & 16 & 0,75 & Tinggi \\
\hline & 4 & 4 & 3 & 3 & 4 & 14 & 0,63 & Tinggi \\
\hline & 5 & 4 & 3 & 3 & 3 & 13 & 0,56 & Cukup \\
\hline & 6 & 4 & 3 & 3 & 3 & 13 & 0,56 & Cukup \\
\hline & 7 & 4 & 3 & 5 & 4 & 16 & 0,75 & Tinggi \\
\hline & 8 & 4 & 4 & 5 & 5 & 18 & 0,88 & Sangat Tinggi \\
\hline & 9 & 4 & 4 & 4 & 3 & 15 & 0,69 & Tinggi \\
\hline & 10 & 4 & 4 & 5 & 3 & 16 & 0,75 & Tinggi \\
\hline & 11 & 4 & 4 & 2 & 3 & 13 & 0,56 & Cukup \\
\hline \multirow{13}{*}{ Design } & 12 & 4 & 3 & 5 & 5 & 17 & 0,81 & Sangat Tinggi \\
\hline & 13 & 4 & 4 & 5 & 4 & 17 & 0,81 & Sangat Tinggi \\
\hline & 14 & 4 & 4 & 5 & 4 & 17 & 0,81 & Sangat Tinggi \\
\hline & 15 & 4 & 3 & 4 & 4 & 15 & 0,69 & Tinggi \\
\hline & 16 & 4 & 4 & 4 & 3 & 15 & 0,69 & Tinggi \\
\hline & 17 & 4 & 4 & 3 & 5 & 16 & 0,75 & Tinggi \\
\hline & 18 & 4 & 4 & 5 & 4 & 17 & 0,81 & Sangat Tinggi \\
\hline & 19 & 4 & 3 & 5 & 4 & 16 & 0,75 & Tinggi \\
\hline & 20 & 4 & 4 & 4 & 4 & 16 & 0,75 & Tinggi \\
\hline & 21 & 4 & 3 & 4 & 3 & 14 & 0,63 & Tinggi \\
\hline & 22 & 4 & 4 & 3 & 5 & 16 & 0,75 & Tinggi \\
\hline & 23 & 4 & 3 & 3 & 5 & 15 & 0,69 & Tinggi \\
\hline & 24 & 4 & 4 & 4 & 5 & 17 & 0,81 & Sangat Tinggi \\
\hline \multirow{6}{*}{ Choice } & 25 & 4 & 4 & 5 & 5 & 18 & 0,88 & Sangat Tinggi \\
\hline & 26 & 4 & 4 & 5 & 5 & 18 & 0,88 & Sangat Tinggi \\
\hline & 27 & 4 & 3 & 3 & 5 & 15 & 0,69 & Tinggi \\
\hline & 28 & 4 & 3 & 3 & 4 & 14 & 0,63 & Tinggi \\
\hline & 29 & 4 & 3 & 4 & 4 & 15 & 0,69 & Tinggi \\
\hline & 30 & 4 & 3 & 4 & 4 & 15 & 0,69 & Tinggi \\
\hline \multirow{3}{*}{ Implementation } & 31 & 4 & 3 & 5 & 3 & 15 & 0,69 & Tinggi \\
\hline & 32 & 4 & 3 & 4 & 5 & 16 & 0,75 & Tinggi \\
\hline & 33 & 4 & 3 & 4 & 5 & 16 & 0,75 & Tinggi \\
\hline
\end{tabular}


Uji Validitas Modul Program Tangkal Hoaks untuk Meningkatkan Keterampilan Pengambilan Keputusan Digital Native dalam Menentukan Berita Hoaks

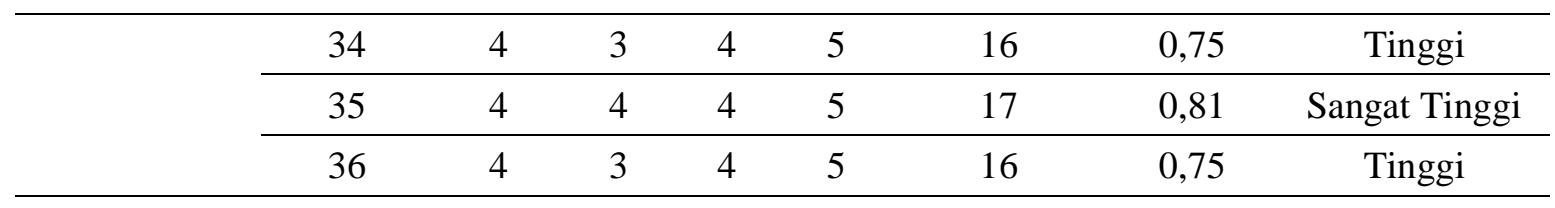

Rentang angka $\mathrm{V}$ yang dapat diperoleh adalah 0-1,00. Setiap skor V yang melebihi dari angka 0,30 maka dapat disimpulkan bahwa butir instrumen tersebut dinyatakan valid (Sugiyono, 2017). Skor angka yang ditampilkan dalam tabel 2 dapat diinterpretasikan sebagai koefisien yang bergerak dari kategori cukup hingga sangat tinggi. Data tabel 2 menunjukkan skor $\mathrm{V}$ bergerak dari angka 0,56-0,88, sehingga menunjukkan bahwa seluruh butir instrumen alat ukur keterampilan pengambilan keputusan dinyatakan valid dengan rentang skor di atas 0,30 .

\section{Pembahasan}

Penelitian ini merupakan penelitian riset validasi modul yang dilakukan mengikuti prosedur pengembangan model 4D yang dikemukakan oleh Thiagarajan (Sugiyono, 2019) yang terdiri dari empat prosedur yaitu define, design, develop, dan dissemination. Prosedur pengembangan dalam penelitian validasi modul ini dimodifikasi menjadi model 3D hanya sampai pada tahap uji coba terbatas (develop) dengan menggunakan metode studi deskriptif. Uji validasi modul dengan expert judgement menghasilkan modul yang dapat menjawab permasalahan penelitian dan siap untuk diuji coba.

Permasalahan yang diangkat berangkat dari kemampuan digital native untuk mendapatkan informasi tanpa batas di era digital saat ini yang tidak selalu diikuti oleh kemampuan generasi untuk mengevaluasi kualitas informasi. Untuk menindaklanjuti permasalahan yang ada, maka dirancang sebuah modul program untuk meningkatkan keterampilan pengambilan keputusan individu dalam menentukan berita hoaks dengan tujuan mencegah penyebaran hoaks. Penyusunan modul dilakukan dengan menentukan metode kegiatang, merancang sesi kegiatan yang disesuaikan dengan aspek keterampilan pengambilan keputusan, hingga merancang alat ukur penelitian.

Modul merupakan sebuah paket instruksi yang disesuaikan dengan kebutuhan peserta dalam menguasai suatu materi. Oleh karena itu, sebelum dapat digunakan maka diperlukan uji validitas pada modul tersebut. Pada penelitian ini dilakukan uji validasi modul oleh empat orang judgement expert yaitu psikolog pendidikan, jurnalis, pakar literasi, dan pemeriksa fakta.

Berdasarkan hasil uji validitas modul, yang telah dilakukan pada modul program tangkal hoaks memiliki validitas yang baik dengan skor validitas oleh expert judgement pada setiap sesinya berkisar dari 0,75-0,88. Modul dapat dikatakan valid karena skor validitas berada di atas 0,50. Begitupun dengan alat ukur penelitian berupa skala keterampilan pengambilan keputusan, nilai Aiken's V berada di atas 0,30 . Sedangkan ketika try out, terdapat tujuh aitem yang tidak valid sehingga tidak dapat digunakan sebagai aitem final.

Penelitian yang relevan dengan penelitian ini ada dalam beberapa bidang, seperti bidang kesehatan yang dilakukan oleh Prasanti (2018) yang mengatakan literasi informasi kesehatan merupakan kegiatan pencegahan dalam menghadapi informasi hoaks yang berguna untuk pengambilan keputusan kesehatan yang tepat dalam menggunakan obat. Selain itu dalam bidang informasi hoaks yang beredar di media sosial juga diteliti oleh (Roozenbeek \& van der Linden, 2019) dengan menggunakan game berbasis aplikasi bernama Bad News. Pertahanan individu dalam menerima berita hoaks dapat ditingkatkan dengan memaparkan dan mengenalkan individu tersebut dengan berita hoaks itu sendiri. Hasil studi menunjukkan bahwa para pemain menjadi 21 persen 
kurang yakin pada berita palsu dibandingkan dengan sebelum mereka bermain.

Program pencegahan hoaks lainnya juga dilakukan dengan berbagai metode seperti sistem analisis visual untuk mengidentifikasi hoaks di media sosial twitter dan pelatihan literasi dalam menerima informasi kasus kriminal (Karduni et al., 2018; Rich \& Zaragoza, 2016). Beberapa program pencegahan hoaks sebelumnya juga terbukti efektif meningkatkan keterampilan individu dalam menerima hoaks.

Modul program tangkal hoaks ini menggunakan metode diskusi sebagai upaya peningkatakan keterampilan pengambilan keputusan. Peningkatan keterampilan pengambilan keputusan dengan diskusi terbukti efektif, seperti penelitian Maloney (2007) yang mengungkapkan bahwa dalam menentukan suatu keputusan, elaborasi dan klarifikasi terkait informasi-informasi yang diperlukan sangat penting. Hal ini dapat dicapai dengan menghadapkan seseorang dengan keadaan nyata dari masalah yang ia hadapi dan diskusi kelompok kecil. Sejalan dengan hal tersebut, Santrock (2007) mengatakan bahwa salah satu strategi untuk meningkatkan keterampilan pengambilan keputusan adalah dengan memberikan peluang kepada individu untuk lebih banyak terlibat dalam pemecahan masalah kelompok. Diskusi kelompok juga efektif dalam meningkatkan harga diri dan gaya coping yang positif (Colakkadioglu \& Celik, 2016).

Berdasarkan saran perbaikan dari validator, penyusunan program dalam modul disesuaikan dengan tahapan perkembangan dan karakteristik digital native, baik dari segi metode maupun bahasa yang digunakan. Digital native sebagai pembelajar merupakan individu yang senang melakukan aktivitas yang melibatkan kelompok (Hameed et al., 2008). Hal ini diimplementasikan di dalam modul dengan memilih metode diskusi sebagai metode pelaksanaan kegiatan. Sehingga digital native dapat bertukar informasi, pendapat, dan pengalaman dengan digital native lain di dalam kelompoknya.

Menurut Prensky (2001) digital native juga memiliki karakteristik lebih mudah memahami gambar daripada teks. Modul kegiatan ini menampilkan karakter atau desain yang menarik, materi disertai banyak contoh berupa gambar dan video. Pemilihan topik berita yang diangkat juga dekat dengan digital native, seperti hoaks pesan instan undian voucher berhadiah, Covid-19, dan aksi demo mahasiswa sehingga meningkatkan ketertarikan dalam pelaksanaan program.

Selain itu, digital native lebih menyukai belajar melalui kegiatan dan praktik daripada membaca atau mendengarkan (Prensky, 2001). Tiap sesi kegiatan, digital native akan mempraktikkan informasi yang diperoleh, terutama pada sesi empat, di mana mereka diajarkan untuk mengakses beberapa media dalam menghadapi hoaks melalui gawai. Melalui praktik pencarian informasi dengan memanfaatkan teknologi dalam program ini mengakomodasi generasi digital native untuk dapat menggunakan teknologi dalam mengklarifikasi berita hoaks yang mereka terima. Hal ini sesuai dengan pendapat Prensky (2001) bahwa digital native berfungsi paling baik saat menggunakan teknologi digital untuk memahami suatu hal.

Psikolog pendidikan memberikan saran untuk tujuan program dituliskan secara jelas hendak mencapai ranah kognitif atau sampai keterampilan. Hal ini diperbaiki berdasarkan teori pengambilan keputusan, di mana menurut Simon (Sari, 2018) aspek pertama dari keterampilan pengambilan keputusan adalah aspek intelligence. Aspek ini mencakup ranah kognitif individu terkait pemrosesan dan penelusuran informasi, barulah kemudian mencapai aspek selanjutnya seperti design, choice, dan implementation yang mencakup ranah keterampilan. Sehingga tujuan program yang ingin dicapai bukan hanya aspek kognitif, akan tetapi juga sampai pada ranah keterampilan. 
Saran dari jurnalis dan pemeriksa fakta, menambahkan beberapa alat atau media yang dapat digunakan untuk memeriksa keakuratan sebuah informasi serta menyesuaikan program dengan teknis pelatihan periksa fakta. Menurut Nurlatifah \& Irwansyah (2019) jurnalisme pemeriksa fakta terdiri atas tiga tahapan yaitu melakukan pemeriksaan fakta melalui proses verifikasi berbagai data dan sumber informasi. Kemudian, platform jurnalisme pemeriksa fakta akan melibatkan publik untuk melihat sumber asli dengan memberikan tautan. Proses terakhir merupakan integrasi yang berarti evaluasi atau penilaian akhir atas klaim fakta yang disajikan sejak awal. Bagian ini menampilkan kesimpulan yang menunjukkan apakah klaim fakta yang diperiksa sejak awal benar atau tidak.

Selain itu, berdasarkan saran validator, batasan mengenai hoaks dan fakta dapat dilihat dengan memeriksa unsur $5 \mathrm{~W}+$ $1 \mathrm{H}$ di dalam berita yang didapat, cek situs berita, dan cek keaslian gambar. Media hoaks yang dibuat juga divalidasi berdasarkan ciri dan batasan mengenai hoaks yang telah dibuat, sehingga diperoleh media hoaks yang menampilkan berita hoaks dan fakta sesuai dengan batasan tersebut.

Pakar literasi memberikan saran penggunaan kata-kata asing diubah ke bahasa Indonesia agar dapat dipahami oleh pembaca. Penggunaan kata-kata teknologi seperti web, platform, diganti dengan kata yang lebih dipahami secara awam. Kalimat di dalam modul dibuat lebih informatif agar pembaca yang merupakan kelompok digital native tertarik akan materi yang disampaikan.

Berdasarkan hal tersebut di atas, modul program tangkal hoaks ini memiliki validitas isi yang baik dan penyusunannya disesuaikan dengan karakteristik digital native. Modul ini diharapkan dapat diuji coba pada kelompok digital native untuk dilihat keefektifan dalam meningkatkan keterampilan pengambilan keputusan dalam menentukan berita hoaks. Saran perbaikan digunakan untuk menyempurnakan modul agar lebih baik dan siap untuk diuji cobakan. Saran perbaikan yang didapatkan dari validator dalam penelitian ditindaklanjuti dengan melakukan revisi modul sehingga didapatkan produk akhir berupa modul program tangkal hoaks untuk meningkatkan keterampilan pengambilan keputusan digital native dalam menentukan berita hoaks yang telah memenuhi kriteria kelayakan dari aspek validitas isi. Dengan demikian modul yang telah dihasilkan ini diharapkan nantinya dapat membantu melatih keterampilan pengambilan keputusan digital native dalam menghadapi hoaks guna mencegah maraknya penyebaran hoaks saat ini.

\section{Kesimpulan}

Berdasarkan hasil penelitian uji validitas modul program tangkal hoaks untuk meningkatkan keterampilan pengambilan keputusan, maka dapat diambil kesimpulan bahwa Modul program tangkal hoaks berada pada tingkat validitas isi yang baik, artinya terdapat kesesuaian isi atau materi dalam tiap sesi modul program tangkal hoaks dengan tujuan yang hendak dicapai.

Hasil validasi modul yang dinilai oleh validator pada setiap sesi dalam modul program tangkal hoaks memiliki rentang skor sesi 1 yang bergerak dari angka 0,75 0,81 , sesi 2 dengan angka 0,75 dan sesi 3 dengan rentang angka $0,75-0,88$.

Hasil validasi modul yang dinilai oleh validator menunjukkan rentang angka skor $\mathrm{V}$ bergerak dari angka 0,75-0,88 dengan kategori tinggi sampai sangat tinggi. Tiap sesi dalam modul program tangkal hoaks memiliki isi yang baik dengan rentang skor di atas 0,50 .

Hasil validasi skala yang dinilai oleh validator menunjukkan rentang angka skor $\mathrm{V}$ bergerak dari angka 0,56-0,88. Skala keterampilan pengambilan keputusan menunjukkan skor $\mathrm{V}$ di atas 0,30 sehingga dapat diartikan bahwa seluruh butir instrumen dinyatakan memiliki validitas isi yang baik. Skala keterampilan pengambilan keputusan untuk aspek intelligence bergerak 
dari angka $0,56-0,88$, aspek design bergerak dari angka 0,63-0,81, aspek choice bergerak dari angka 0,63-0,88, dan aspek implementation bergerak dari angka 0,690,81 .

\section{Saran}

Berdasarkan hasil penelitian yang telah dicapai serta mengingat masih banyaknya keterbatasan dalam penelitian ini, maka peneliti memberikan beberapa saran sebagai bahan pertimbangan dalam mengembangkan program untuk mencegah maraknya hoaks terutama untuk digital native sebagai pengguna internet terbanyak di Indonesia. Penelitian ini juga dapat dijadikan program salah satu kegiatan di luar proses belajar mengajar ataupun sebagai salah satu materi pengantar dalam kegiatan pengenalan sekolah atau kampus. Saran bagi peneliti selanjutnya untuk dapat mengembangkan dan uji coba program tangkal hoaks ini untuk melihat efektivitas program terhadap peningkatan keterampilan pengambilan keputusan digital native dalam menentukan hoaks.

\section{Daftar Pustaka}

APJII. (2019). Infografis Penetrasi \& Perilaku Pengguna Internet di Indonesia.

Azwar, S. (2018). Metode Penelitian Psikologi. Pustaka Belajar.

Bakri, S., Zulhazmi, A. Z., \& Laksono, K. (2019). Menanggulangi Hoaks dan Ujaran Kebencian Bermuatan Isu Suku, Agama, Ras, dan Antar Golongan di Tahun Politik. Al-Balagh: Jurnal Dakwah Dan Komunikasi, 4(2), 199-234.

Colakkadioglu, O., \& Celik, D. B. (2016). Karar verme beceri eğitimi programının karar vermede özsayg1 ve karar verme stillerine etkisi. Egitim Arastirmalari - Eurasian Journal of Educational Research, 2016(65), 259276. https://doi.org/10.14689/ejer.2016.65.1 5
Erdelyi, K. M. (2020). The Psychological Impact of Information Warfare \& Fake News. https://www.psycom.net/iwar.1.html.

Greenwood, S., Perrin, A., \& Duggan, M. (2016). Social Media Update 2016. https://www.pewresearch.org/internet/ 2016/11/11/social-media-update-2016/

Hameed, S., Badii, A., \& Cullen, A. J. (2008). Effective e-learning integration with traditional learning in a blended learning environment. Proceedings of the European and Mediterranean Conference on Information Systems, EMCIS 2008, May 2014.

Indonesia, Kementerian Komunikasi dan Informatika. Jakarta: Kementerian Komunikasi dan Informatika, 2019.

Karduni, A., Wesslen, R., Santhanam, S., Cho, I., Volkova, S., Arendt, D., Shaikh, S., \& Dou, W. (2018). Can you verifi this? Studying uncertainty and decision-making about misinformation using visual analytics. 12th International AAAI Conference on Web and Social Media, ICWSM 2018, Icwsm, 151-160.

Maloney, J. (2007). Children's roles and use of evidence in science: An analysis of decision-making in small groups. In British Educational Research Journal (Vol. 33, Issue 3). https://doi.org/10.1080/014119207012 43636

Manalu, S. R., Pradekso, T., \& Setyabudi, D. (2018). Understanding the Tendency of Media Users to Consume Fake News. Jurnal ILMU KOMUNIKASI, 15(1), 1-16.

Media Release, L. M. (2018). Pemetaan hoaks di indonesia. 1-5.

Muannas, M. (2018). Proses Gatekeeping Terkait Redistribusi Konten Media Sosial: Persfektif Generasi Z. Jurnal Jurnalisa, 4(2), 256-270. https://doi.org/10.24252/jurnalisa.v4i2. 6898 
Uji Validitas Modul Program Tangkal Hoaks untuk Meningkatkan Keterampilan Pengambilan Keputusan Digital Native dalam Menentukan Berita Hoaks

Nurlatifah, M., \& Irwansyah, I. (2019). FactChecking Journalism sebagai Platform Kolaborasi Human and Machine pada Jurnalisme Digital. Jurnal Komunikasi, $13(2)$ 121-134. https://doi.org/10.20885/komunikasi.v ol13.iss2.art1

Prasanti, D. (2018). Health Information of Literation as Prevention Processes of Hoax Information in the Use of Traditional Medicine in Digital Era (Literasi Informasi Kesehatan sebagai Upaya Pencegahan Informasi Hoax dalam Penggunaan Obat Tradisional di Era Digital). Journal Pekommas, 3(1), 45.

https://doi.org/10.30818/jpkm.2018.20 30105

Prensky, B. M. (2001). Digital Natives, Digital Immigrants. 1-6.

Rahmawati, D., Kesa, D. D., Suciati, P., \& Lusia, A. (2019). Karakteristik Generasi Digital Natives Dalam Lingkungan Digital . Studi Kasus Kampung Digital Vokasi Ui. 381-386.

Rich, P. R., \& Zaragoza, M. S. (2016). The continued influence of implied and explicitly stated misinformation in news reports. Journal of Experimental Psychology: Learning Memory and Cognition, 42(1), 62-74. https://doi.org/10.1037/xlm0000155

Roozenbeek, J., \& van der Linden, S. (2019). Fake news game confers psychological resistance against online misinformation.

Palgrave Communications, $5(1)$. https://doi.org/10.1057/s41599-0190279-9

Rusadi, U. (2014). Konsumsi Berita Lintas Media Massa Konvensional Dan Internet. Jurnal Penelitian Dan Pengembangan Komunikasi Dan Informatika, 4(3), 173-187.

Santrock, J. W. (2007). Adolescence: Perkembangan Remaja (Keenam). Erlangga.
Sari, F. (2018). Metode Pengambilan Keputusan. Deepublish.

Septiani Rosana, A. (2010). Kemajuan Teknologi Informasi dan Komunikasi dalam Industri Media di Indonesia. Gema Eksos, 5(2), 144-156. https://www.neliti.com/id/publications/ 218225/kemajuan-teknologi-informasidan-komunikasi-dalam-industri-mediadi-indonesia

Siswoko, K. H. (2017). Kebijakan Pemerintah Menangkal Penyebaran Berita Palsu atau 'Hoax.' Jurnal Muara Ilmu Sosial, Humaniora, Dan Seni, $\quad 1(1), \quad 13$. https://doi.org/10.24912/jmishumsen.v $1 \mathrm{i} 1.330$

Sugiyono. (2017). Metode Penelitian Pendidikan Pendekatan Kuantitatif, Kualitatif, dan $R \& D$. Alfabeta.

Sugiyono. (2019). Metode Penelitian Pendidikan (Kuantitatif, Kualitatif, Kombinasi, $R \& D$ dan Penelitian Pendidikan). Alfabeta.

Supratman, L. P. (2018). Penggunaan Media Sosial oleh Digital Native. Jurnal ILMU KOMUNIKASI, 15(1), 47-60. https://doi.org/10.24002/jik.v15i1.1243 